\title{
Appearances of Local Prolific Ewes in Semarang Regency Central Java Indonesia
}

\author{
Enny Tantini Setiatin, Sutiyono*, Daud Samsudewa, Sutopo and Yon Supri Ondho \\ Faculty of Animal and Agriculture Science, University of Diponegoro, Semarang, Indonesia \\ *Corresponding author e-mail: barep.sutiyono@gmail.com
}

\begin{abstract}
The present study examined the quantitative and qualitative physical parameters of prolific local ewes in Bawen and Jambu districts, Central Java. We used purposive sampling to select and categorized 132 local, three-lambing ewes into three groups based on their prolific capacity: 66 single, 49 twins and 17 triplets. The data were subjected to analysis of variance using Chi-Square. The result showed that many quantitative properties of prolific ewes resembled those of fat-tailed sheep: thin tail, highly significant $(P<0.01)$ compared to fat tails; straight face, highly significant $(P<0.01)$; and fewer convex face and short body, significant $(P<0.05)$ with a tall body in the non-prolific ewes. Few prolific ewes had big ears and black-white wool and significantly different $(\mathrm{P}<0.05)$ from the non-prolific ewes. Conclusively, local prolific ewes had a qualitative appearance more closely related to that of thin-tailed ewes, but greater quantitative performances than the non-prolific ewes.
\end{abstract}

Keywords: body appearance, character qualitative, character quantitative, ewes, prolific

\begin{abstract}
Abstrak. Penelitian ini bertujuan untuk mengetahui sifat kualitatif dan kuantitatif tubuh domba lokal prolifik betina, di Kabupaten Bawen dan Jambu, Jawa Tengah. Materi penelitian ditentukan secara purposive sampling yaitu induk domba yang telah melahirkan minimal tiga kali. Jumlah 132 ekor induk domba lokal yang bagi menjadi tiga kelompok berdasarkan kapasitas prolifikasinya yaitu selalu beranak tunggal, pernah kembar dan kembar tiga atau lebih masing-masing 66, 49 dan 17 ekor. Parameter penelitian adalah sifat kualitatif dan kuantitatif. Data yang diperoleh dianalisis dengan menggunakan analisis Chi square and uji variance. Hasil penelitian menunjukkan bahwa penampilan sifat kuantitatif induk domba prolifik banyak menyerupai domba ekor gemuk, yaitu parameter ekor tipis lebih banyak dan sangat signifikan dari ekor gemuk, tipe wajah lurus sangat banyak dan sangat signifikan $(P<0,01)$ wajah cembung dan tubuh pendek lebih sedikit dan signifikan $(P$ $<0,05)$ dengan tubuh tinggi, pada induk domba tidak prolifik. Penampilan telinga besar dan warna wol hitamputih domba prolifik berjumlah lebih sedikit dan berbeda nyata $(P<0,05)$ dibandingkan domba yang tidak produktif. Penampilan lebar pinggul, llium panjang dan lingkar dada menunjukkan perbedaan secara nyata lebih tinggi $(\mathrm{P}<0,05)$ dari pada domba non prolifik. Kesimpulan penampilan sifat kualitatif domba lokal prolifik berhubungan lebih erat dengan penampilan domba ekor tipis betina, tetapi mereka memiliki parameter sifat kuantitatif yang lebih besar dari pada domba non-prolifik.
\end{abstract}

Kata kunci: penampilan tubuh, sifat kualitatif, sifat kuantitatif, induk domba, prolific

\section{Introduction}

Prolific sheep is a vital asset for the development of future sheep. Garole and Kendra sheep are very productive because their FecB gene is used to convert non-prolific sheep to prolific by backcrossing for six generations (Tunji et al., 2010; Sagar et al., 2017). The prolific characters of sheep are determined by many types of genes, i.e., BMP15 (Wang et al., 2011; Kaczor, 2017) and genes that have not undergone mutations, i.e., FecXG and FecXI (Holanda et al., 2017). The prolific traits of sheep in Indonesia come from the gene mutation of Javanese sheep, that are inherited to their offspring (Davis et al., 2002).

The breeding of indigenous sheep in Semarang Regency has shifted to crossbreed with bigger body and produce more meat. In Semarang District, most farmers favor the crossbreed of Javanese sheep (thin-tailed sheep) and a fat tailed sheep. However, most sheep breeding practice overlooks the future development of sheep although people will need more sheep in the future. In order to increase sheep population in the future, breeders need to take into account the genetic 
superiority of sheep to produce lambs through prolific genes. China government has Funiu white goats that can produce three lambs per kidding. At first it was only $24.74 \%$, then it spread in five development areas, which eventually grew to 700,000 (Wang et al., 2011). Ewes selected for their prolific properties show a greater effect on the variability of total offspring per lambing (Martin et al., 2014; Ramírez et al., 2014). The number of prolific ewes in farms is generally very small, so breeding business should be developed to produce more prolific breed. Another factor to consider is the close relation to reproductive performance of ewes. Gene analysis for reproductive system is considerably useful but also complicated; therefore, it is necessary to choose ewes by considering factors that are closely related to prolific characteristics (Riofrio et al., 2016).

One way to produce sheep with the ability to give birth to triplets or more is by selecting sheep with fecundity genes. A strategic breeding program should separate ewes into 2 groups, the prolific and non-prolific (Kumar et al., 2006). The prolific group is mated with prolific male offspring to get more productive types (Holmøy et al., 2017; Kumar et al., 2006). Heterozygous ewes carrying mutated BMP-15 gene contribute significantly to increase the number of the next-generation ovulations (Wang et al., 2011). The efforts to increase the number of fertile sheep should include selecting sheep with big body size because it is associated with prolificacy level (Naqvi et al., 2007; Wang et al., 2011).

The main problem in the development of prolific ewes is the higher rate of lamb mortality than the single births. Previous studies reported the mortality rate of single and twin birth in Ossisimi lambs ( $10.7 \%$ vs. $50 \%)$, Rahmani lambs ( $4.2 \%$ vs. $41.7 \%$ ), and Romanov lambs ( $0 \%$ and 7.6\%) (Balabel, 2010) The main factor of lamb mortality is low survival after birth, that is influenced by low birth weight and poor conditions. The contributing factors to low birth weight include nutrient intake (Balabel, 2010), rearing management (Balabel, 2010; Getachew et al, 2016), nutrition and parity (Balabel, 2010), body condition score of ewes (Balabel, 2010; Kerslake et al., 2010), and the interaction between feed nutrient and body condition score of ewes (Thomas et al., 2015).

Low vitality of lamb at birth is due to inbreeding depression (Barezak et al., 2009; Ceyhan et al., 2011), extreme feed shortages during pregnancy and lactation (Kerslake et al., 2010; Taye et al., 2011), poor conditions of infants before birth (Naqvi et al., 2007), and dystocia (Nogalski and Mordas, 2012). One effort to obtain lambs with high birth weight and good conditions is through the ewe selection based on abdomen and pelvis factors. Abdominal cavity contributes to support fetal growth (Naqvi et al., 2007) and the width of pelvic cavity can accelerate the process of birth (Nogalski and Mordas, 2012). Body length and coxae tuber indicate that goats are able to bear more kids (Haldar et al., 2014). The identification of ewes' body size can be used as the basis for selecting ewes that potentially give triplets birth. Ewes with large posture ewes are required to confirm the number of lambs that can be produced because it relates to the ability of prolificacy (Wang et al., 2011). Wide pelvic cavity will minimize the incidence of birth difficulty (Nogalski and Mordas, 2012). Therefore, the selection based on ilium bone length and the hip width of ewes potentially improves triplet birth and better life performance of the lambs.

\section{Materials and Methods}

This study was carried out by surveying local ewes that were traditionally reared in Bawen and Jambu districts, Semarang. Feed given was forage (grass, legume, or leaves) with optional bran. The nutrient content consisted of 8.74$11.23 \%$ crude protein and $1797.00-1859.00 \mathrm{kcal}$ energy metabolism. A total of 132 ewes with at 
least three-time lambing were selected by purposive sampling and grouped into three according to the litter size: ewes that always gave birth to single lamb (L1), twins (L2), and more than two (LM2) per birth as many as 66, 49, and 17 heads, respectively. The LM2 was declared as prolific ewes. The qualitative and quantitative data collection was performed when visiting the breeder 's cage.

The qualitative data and measurements were the comparison of a pair of traits as follows. Tails: fat vs. thin tail (Figure 1); front: convex vs. flat face (Figure 2); wool: white coat vs. mix white and black; ear: large $(>11.26 \mathrm{~cm})$ vs small ears $(<11.26 \mathrm{~cm})$; and body: tall $(>55.23$ $\mathrm{cm})$ vs. short $(<55.23 \mathrm{~cm})$.

The quantitative data were measured while

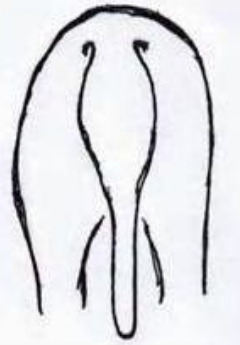

Fat tail

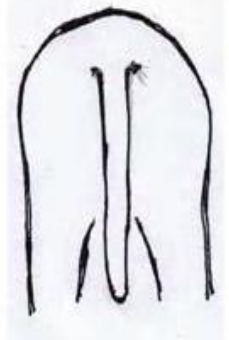

Thin tail

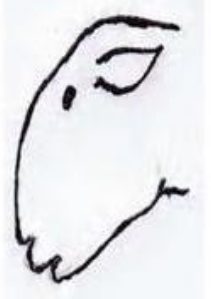

Convex face the ewes stood on four legs in a rectangular position. The quantitative data and measurements (in $\mathrm{cm}$ ) include: a) body length: between the tip of the joint of the humerus and the scapula to the tip of the tuber ischium; b) body height: from the tip of the distal phalanx front legs perpendicular to the tip withers; $c$ ) ileum length: from the ilium bone joints and lummbalis to the end of the tuber of ischium; d) hip width: the distance between the tip of joints of lumbar bone and right and left ilium; e) chest girth: measured on circular chest on the back and sticking on front legs. Figure 3 presents the detailed method of body measurements.

The analysis of qualitative data (body, faces, ears, wool color, ears, and tail) used the Chisquare. The quantitative data (body length, body high, hip width, ileum length, and chest circumference) were subjected to analysis of variance (Steel and Torrie, 1981).

Figure 1. Shape of sheep tail

Figure 2. Shape of sheep face

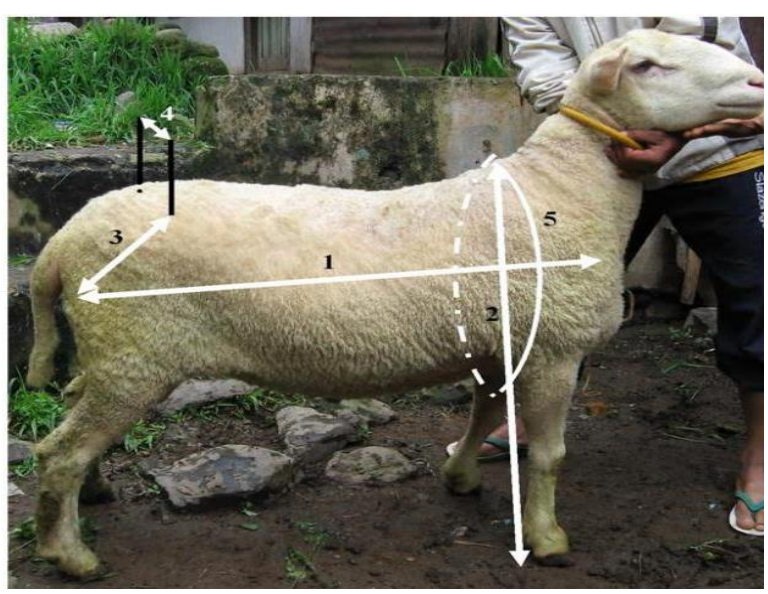

Figure 3. The method of ewes measurement 


\section{Results and Discussion}

The qualitative appearance of ewes giving birth to single, twins, and more than two kids per lambing in Bawen and Jambu districts, Semarang Regency showed a great variance between the thin-tailed indigenous Javanese ewes and the fat-tailed ewes (Table1). Besides having thin tails, the indigenous Javanese ewes had straight face profiles, large ears, blackwhite wool, and small body postures, while the fat-tailed sheep had a convex face profile, small ears, and tall body posture.

Table 1 shows that the qualitative nature of ewes LM2 based on statistical analysis resembles more to the thin-tailed sheep than the fat-tailed ones. Prolific ewes with thin tails looked more (0.01) like the fat tail with a very straight face $(P<0.01)$ compared to convex face and short body $(P<0.05)$ rather than tall body. The quantitative nature showed that prolific sheep with small ears were few and very significant $(P<0.01)$ than those with large ears, and the black-white wool were significantly fewer $(\mathrm{P}<0.05)$ than the white wool.

In smallholder ewe breeding of ewes, the number of ewes and lambing percentage are the key success factors. Ewe crossbreeding may improve their maternal and neonatal behavior, which in turn leads to better performance and higher survival rate for the next offspring (Darwish et al., 2010). Ewes that have triplet or more at lambing in Bawen and Jambu Regency were only 17 heads (12.88\%). The characteristics of thin and fat ewes crossbred were thin tailed, small ears, white wool, and short body. These prolific traits in ewes are due to DNA mutation in gene $\mathrm{FecB}$ of Java sheep (Davis et al., 2002; Pardeshi et al., 2005). Efforts to increase the number of prolific ewes may include the selection and crossing methods. Good breeding strategic programs are chosen to increase the number of prolific ewes (Kumar et al., 2006). A group of non-prolific ewes mated with prolific male sheep may result in prolific breeds (Holmøy et al., 2017; Kumar et al., 2006). The reproductive properties of the prolific sheep that will be reproduced can be obtained from the crossbreeding between the tail-fat Morkaraman and the descendants of Romanov (Korkmaz and Emsen, 2016).

The crossbreed of ewes might improve their maternal and neonatal behavior, which might in turn lead to better performance and higher survival rate for the next generation (Darwish et al., 2010). Birth type significantly and negatively affects birth weight and survival rates of triplet lambs, and the rate of lamb mortality increases with litter size (Guyoti et al., 2015). The mortality of Mpumalanga lambs which was single or twin during birth (Getachew et al, 2016). The mortality of embryo in uterus for ewes bearing three and two embryo was $28.6 \%$ and $38.1 \%$ (Naqvi et al., 2007).

Table 1. Percentage of qualitative exterior variables of ewes giving birth single (L1), twin (L2) and more than two Lambs (LM2) in Bawen and Jambu Districts. Semarang Regency.

\begin{tabular}{|c|c|c|c|c|c|}
\hline \multirow{2}{*}{ Parameter } & \multirow{2}{*}{ Variable } & \multicolumn{4}{|c|}{ Birth Type } \\
\hline & & L1 & $\mathrm{L} 2$ & LM2 & L1, L2 and LM2 \\
\hline Ewes & Total & 66 & 49 & 17 & 132 \\
\hline Presented & $(\%)$ & 50.00 & 37.12 & 12.88 & 100 \\
\hline Tail & Fat: Thin (\%) & 51.51: 48.49 & $28.57: 71.43^{* *}$ & $11.75: 88.25^{* *}$ & 37.88: $62.12^{* *}$ \\
\hline Faces & Convex: straight (\%) & $21.21: 78.79 * *$ & 28.57: $71.43^{* *}$ & 52.94: 47.06 & 28.03: $71.97^{* *}$ \\
\hline Ears & Small: Big (\%) & $21.21: 78,79 * *$ & 73.47: $26.53^{* *}$ & 82.35: $17.65^{* *}$ & 69.70: $30.30 * *$ \\
\hline Wool Color & Whit: Black-white (\%) & $55.32: 44.68^{*}$ & $58.33: 41.67^{*}$ & 76.47: $23.23^{* *}$ & $58.33: 41.67^{*}$ \\
\hline Body & High : Short (\%) & $54,54: 45.46^{*}$ & $38.76: 61.24^{* *}$ & 17.65: $82.35^{* *}$ & $43.93: 56.07^{*}$ \\
\hline
\end{tabular}


Table 2. The Exterior Appearances of Three Group of Ewes with the Ability to Give Birth Single Lamb, Twin and More than two Lambs in District Bawen and Jambu Semarang Regency.

\begin{tabular}{llll}
\hline \multirow{2}{*}{ Parameter } & \multicolumn{3}{c}{ Birth Type } \\
\cline { 2 - 4 } & L1 & L2 & LM3 \\
\hline Body length $(\mathrm{cm})$ & $59.45 \pm 4.58^{\mathrm{a}}$ & $61.41 \pm 4.94^{\mathrm{ab}}$ & $63.00 \pm 4.94^{\mathrm{b}}$ \\
Body height $(\mathrm{cm})$ & $54.95 \pm 6.41$ & $56.86 \pm 5.01$ & $55.53 \pm 4.57$ \\
Hip width $(\mathrm{cm})$ & $16.94 \pm 4.13^{\mathrm{a}}$ & $19.00 \pm 6.38^{\mathrm{b}}$ & $19.88 \pm 5.81^{\mathrm{b}}$ \\
Length ileum $(\mathrm{cm})$ & $21.63 \pm 10.12^{\mathrm{a}}$ & $24.08 \pm 10.21^{\mathrm{b}}$ & $27.59 \pm 11.39^{\mathrm{B}}$ \\
Chest girth $(\mathrm{cm})$ & $70.78 \pm 8.62^{\mathrm{a}}$ & $71.94 \pm 7.09$ & $73.29 \pm 17.94^{\mathrm{a}}$ \\
\hline
\end{tabular}

Superscript with small letters in all line was significant $(P<0,05)$ and superscript with big letters in all line was highly significant $(P<0,01)$

Effective programs for the dissemination of superior germ plasm were crossing, selecting, maintaining from birth to their birth, giving birth, and giving attention to environmental adaptation (Ashour et al., 2015). The qualitative appearance (body length, body height, ileum length and chest girth) of ewes giving birth single, twins, and more than two lambs per birth is presented in Table 2.

Body length represents the length of the spine that is associated with meat production and plays an important role in the abdominal cavity. A large abdominal cavity strongly correlates to the survival of postnatal lambs until weaning. Table 2 shows that the body of the longest prolific sheep was highly significant $(P<0.01)$ from $L 1$ sheep, and significant $(P<0.05)$ with $L 2$, but no significant difference between L1 and L2. The long body of the prolific female plays a role in expanding the uterine space in the direction of the body axis at the time of pregnancy, so it can contain more kid and a higher survival rate.

The LM2 ewes have the longest body while L2 and L1 sheep have the shortest body. Body height measurements are the common parameters to classify large or small sheep. The result of statistical analysis showed nonsignificantly different height across the three groups because the breeders in Bawen and Jambu sub-districts were targeting more meat production rather than more litter size. Therefore, ewes that had large body were chosen. lleum bone, along with the cervical bone, forms pelvic cavity, causing a wide or long pelvic hole. Pelvic cavity plays a role in providing space for fetal growth and ease or difficulty in labor. The length of ileum bone will make pelvic cavity a wider space for fetal growth and also ease the labor. The ileum bone length between L1 and L2 was significantly different $(P<0.05)$. Correlation between $\mathrm{L} 1$ and LM2 was very significant $(P<0.01)$, but between L3 and LM2 was not significant. LM2 and L2 had the same length of ileum bone, but L1 was shorter. A wider ileum bone in ewes was very useful for labor. There was no difficulty in parturition, and it can improve the survival of lambs.

The hip width of ewes is a parameter to a narrow or wide pelvis, as well as the success of labor. There was no significant difference in hip width between $L 1$ and L2, L2 and LM2, but hip width of L1 and LM2 was significantly different $(P<0.05)$, so LM2's hip width was greater than L1 and L2's. A large hip widths will make labor easier.

The chest circumference is formed from the sternum where a thorax space is located. The chest girth to the abdominal cavity is a place for prenatal growth. Chest girth between L1 and L2 ewes was not significant, that of $L 1$ and $L 2$ was significantly different $(P<0.05)$ from $L M 2$. Therefore, LM2 had the largest chest girth.

The body size of ewes is considered a contributing factor to the growth of pre- and postnatal lambs (Muhammed et al., 2017). The diversity of birth types of ewes in local areas is 
probably due to the major prolific genes, so to identify the presence of prolific genes, each individual ewe needs to be detected. Body weight of ewes during labor is closely related to the number of lambs born (Mishra et al., 2009; Liu et al., 2014; Heba et al., 2021). The difference in influences between size and sheep on reproductive performance is related to the sheep prolificacy (Kolte et al., 2005). Body size and body condition score significantly $(P<0.05)$ affected the percentage of lambs and birth weight (Sejian et al., 2016). Therefore, selection of the body size of ewes can increase the size of lambs significantly and the total litter size (Piper et al., 2007).

Ewes having triplets birth have wide hips, a long ileum, and bigger chest girth than the single lambing ewes. Therefore, body size is the potential basis for selecting prolific ewes to increase litter size. The selection of prolific can inherit reproductive traits, help embryonic growth in the womb, and support offspring postnatal survival (Andres et al., 2020). Normal intra uterine fetal development is related to survival, lamb health, and productivity of ewes (Khojasthek, 2012).

Prolific ewes have obvious appearances that contribute to ease the gestation and lambing process, as well as affecting the survival rate of the lambs and ewes (Cemal and Karaca, 2007). Embryo mortality in uterus may be due to the small capacity of uterus that limits the addition of the number of embryos (Naqvi et al., 2007). The varied litter sizes are influenced by the competitive ability and survival in uterine until the birth (Gronqvist et al., 2020) that is related to race, nutritional status, age, and genetic factors (Khojasthek, 2012). Positive interactions between nutritional status and body condition scores affect both the condition of ewe and of pregnancy and lactation. Therefore, lamb has the potential to survive (Thomas et al., 2015).

Haldar et al. (2014) explains that the measurements of body and meat type of doe indicating a positive correlation to increase multiple fetus are neck length $(>22.78 \mathrm{~cm})$, body length $(>54.86 \mathrm{~cm})$, withers height $(>48.85$ $\mathrm{cm})$, croup height $(>50.67 \mathrm{~cm})$, distance between tuber coxae bones $(>11.38 \mathrm{~cm})$, and distance between tuber ischii bones $(>4.56 \mathrm{~cm})$.

This study also shows that body measurements of prolific ewes that can support embryo growth in uterine were body length, hip width and chest girth of ewes, abdomen space which can extend uterus during pregnant. Large body sizes describe a large stomach space so that uterine cavity can expand during pregnancy. Extensive uterus is positively correlated to growth, health and neonatal and after birth survivability. The slow growth of lamb in uterine can lead to the low levels of the birth weight and survival, thus causing dystocia and high mortality of post natal (Guyoti et al., 2015). Another potential cause of dystocia is a narrow pelvic cavity. The width of pelvic cavity in heifers contributes to reduce the occurrence of dystocia through the selection of pelvic dimension (Nogalski and Mordas, 2012). Mortality rate which occurred on the first day of prenatal life of lambs. It is possibly due to low birth weight and lambing difficulty (Guyoti et al., 2015).

\section{Conclusions}

The qualitative appearance of prolific local ewes is more closely related to the thin-tail ewes, the greater quantitative performances than the non-prolific ewes. In order to obtain prolific ewes, we recommend selecting ones with a thin tail, straight face, short posture, long body, wider hips wider, long ileum bone, and wide chest circumference.

\section{Acknowledgement}

This paper is part of a research project funded by the Competitive Grants Program of Higher Education. The authors are grateful to Dirjen DIKTI for the research opportunity and to the Head of Department of Animal science and 
Fisheries Semarang Regency for the research permit in Jambu and Bawen districts.

\section{References}

Andres, S, C Valdes, A Santos, J Mateo, and FJ Giraldez. 2020. Effect of birt weight on animal performance, fattening traits and meat quality of lambs. Animals. 10: 2364-2376. Doi: 10.3390/ani10122364.

Ashour, G, NA Ashmawy, Sh M Dessouki, and $\mathrm{OHI}$ Shihab. 2015. Blood hematology, metabolites and hormones in newborn sheep and goat from birth to weaning. Inter. J. of Adv. Res. 3 (7): 13771386

Balabel, TMM. 2010. The Relationship between sheep management and lamb mortality. Inter. J. Biol. Food, Vet. and Agric. Eng. 4 (5): 55-60.

Ceyhan, A, A Kaygisiz, and T Sezenler. 2011. Effect of inbreeding on preweaning growth traits and survival rate in Sakiz sheep. J. of anim. \& Plant Sci. 21 (1); 1-4.

Darwish, RA, UA Abou-Ismail, and SZ El-Kholya. 2010 Differences in post-parturient behaviour, lamb performance and survival rate between purebred Egyptian Rahmani and its crossbred Finnish ewes. journal homepage: www.elsevier.com/locate/smallrumres. Small Ruminant Res. 89: 57-61 Accessed: December 02, 2018

Davis, GH, SM Galloway, IK Ross, SM Gregan, J Ward, BV Nimbkar, PM Ghalsasi, P Mulsant, F Lecerf, JP Hanrahan, GE Bradford dan T Wilson, C Mimbkar, GD Gray, Subandriyo, I Inonunu, B Tiesnamurti, E Martyniuk, E Eythorsdottir. 2002. DNA Test in Prolifics Sheep from Eight Cauntries Provide New Evidence on Origin of the Booroola (FeeB) Mutation. Biol. of Reprod. 66 (6) : 1869-1874.

Getachew, T, A Haile, M Wurzinger, B Rischkowsky, S Gizaw, A Abebe, and J Solkner. 2016. Review of sheep crossbreeding based on exotic sires and among indigenous breeds in the tropics: An Ethiopian perspestive. Afr. J. Agric. Res. 11(11): 901-911. DOI: 10.5897/AJAR2013. 10626

Gronqvist, GV, RE Hickson, PR Kenyon, ST Morris, KJ Stafford, and RA Corner-Thomas. 2020. Behaviour of twin and triplet-born lambs and their dam 3 to 18 hours after birt is not a useful predictor of lamb survival to weaning. AsianAustralas. J. Anim. Sci. 33(11); 1848-1857. https://doi.org/10.5713/ajas.19.0479.

Guyoti, VM, M de Souza Farias, ML Dalmolin, CH Poli, V Schmidt, and FD Gonzalez. 2015. Effect of shearing during pregnancy on productive performance in the post-partum period of ewes on extensive husbandry. Cienc. Anim. Bras. 16(2): 217-224. Doi: 10.1590/1089-6891v16i233219
Haldar, A, P Pal, M Datta, R Paul, S K Pal, D Majumdar, CK Biswas, and S Pan. 2014. Prolificacy and Its Relationship with Age, Body Weight, Parity, Previous Litter Size and Body Linear Type Traits in Meat-type Goats. Asian Australas. J. Anim. Sci. 27 (5); 628-634.

Heba, AAE, HR Metawi, AS Adenaike, M El-Komy Shimma, MR Anous, OP Sunday, and AS Khatab. 2021. Genetic parameters, phenotypic and genetic trends of litter size on different breeds of goat in egypt. Trop. Anim Health Prod. 53(2):286. DOI: 10.1007/s11250-021-02721-3.

Holanda, GML, JC Oliveira, DMF Silva, SSN Rocha, V Pandolfi, M Adriao, and A Wischral. 2017. Survey of mutations in prolificacy genes in Santa Ines and Morada Nova sheep. Arq. Bras. Med. Vet. Zootec., 69 (4): 1047-1053.

Holm $\varnothing y$, IH, S Waage, EG Granquist, TM L'AbeeLund, C Ersdal, L Hektoen, and R. Sørby. 2017. Early neonatal lamb mortality: postmortem findings. Anim. 11(2): 295-305. Doi:10.1017/S175173111600152X.

Kaczor, U. 2017. Genes Involved Litter Size in Olkuska Sheep. In Chapter 12, Genetic Polymorphisms. Open Access book publisher http://dx.doi.org/10.5772/intechopen.69205.

Accessed: December 02, 2018

Kerslake, JI, PR Kenyon, ST Morris, KJ Stafforrd, and PCH Morel. 2010. Does offering concentrate supplement during late pregnancy affect twinand triplet-bearing ewe and lam performant. New Zealand J. Agric.Res. 53 (4): 315-325.

Khojasthek, SMB. 2012. Prenatal development of Iranian goat fetuses. Inter. Res. J. Appl. Basic Sci. 3 (10): 2022-2024.

Kolte, AP, AK Mishira, S Kumar, L Arora, VK Singh. 2005. A study on effect FecB gene on body weight in garole $x$ malpura sheep. AsianAustralasian J. Anim. Sci. 18 (10) : 1379-1382.

Korkmaz, MK, and E Emsen 2016. Growth and reproductive traits of purebred and crossbred Romanov lambs in Eastern Anatolia. Anim Reprod., 13 (1): 3-6.

Kumar, S, AP Kolte, and VK Singh. 2006. Twinning in Marwari and Bharat Merino ewes and its relationship Booroola $\mathrm{FecB}$ mutation. Indian J. Biotech. 5: 482-145.

Liu, Q, Z Pan, X Wang, W Hu, R Di, Y Yao, and M Chu. 2014. Progress on major genes for high fecundity in ewes. Front. Agr. Sci. Eng. 1(4): 282-290. Doi: 10.15302/J-FASE-2014042.

Martin, P, J Raoul1, and L Bodin. 2014. Effects of the FecL major gene in the Lacaune meat sheep population. Genet. Selec. Evol. 46 (1): 48-52

Mishra, AK, AL Arora, and S Kumar 2009. Increasing prolificacy and ewe efficiency in sheep through 
FecB gene introgression Current Sci. 97 (6) : 925930.

Muhammed, N, K Alemayehu, and T Getachew. 2017. On-farm phenotypic characterization of indigenous sheep population and its cross with Awassi in selected Districts of South Wollo, Amhara, Ethiopia. Tropical Dryland. 1(1): 1-11. DOI: 10.13057/tropdryland/t010101.

Naqvi, SMK, A Joshi, D Kumar, R Gulyani, VP Maurya, S. Saha. JP Mittal, and V K Singh. 2007. Developmental competence, birth and survival of lambs following transfer of twin or triple embryos of dwarf size prolific donor into large size non-prolific recipient sheep. J. of Cell and Anim Biol. 1 (5) : 082-086.

Nogalski, Z, and W Mordas. 2012. Pelvic Parameters in Holstein-Friesian and Jersey Heifers in Relation to Their Calving. Pakistan Vet. J. 32 (4): 507-510.

Pardeshi, V C, M N Sainani, JF Maddox, PM Ghalsasi, C Nimbkar, and VS Gupta. 2005. Assessing the role of $\mathrm{FecB}$ mutation in productivity of Indian sheep. Current Sci. 89 (5):887-890

Piper LR, AA Swan, and HG Brewer. 2007. Effects lifetame reproductive performance of phenotypic selection for fleece weight fibre diameter body weight and related selection indexes. Proc. Assoc. Advmt. Anim. Breed. Genet. $18: 374-377$.

Ramírez, RBL, HFM Sevilla, RZ Bustillos, JPR Ugalde, and DG. Mendoza. 2014 Analysis of the 3' end regions of the GDF9 and BMPR1B genes in Blackbelly sheep from Yucatán, Mexico. Cien. Inv. Agr. 41(1):123-128.

Riofrio, ELA, JBS Ferraz, and EC Mattos. 2016. Influence of non-genetic factors on growth and reproductive traits of sheep Santa Inês in extensive systems. Livestock. Research. for Rural Development. 28 (7): Article 3121. Retrieved January 14, 2017, from
http://www.Irrd.org//rrd28/7/agui28121.html. Accessed: December 02, 2018

Sagar NG, S Kumar, A Baranwal, and AR Prasad. 2017. Introgression of Fecundity Gene (FecB) In Non-Prolific Sheep Breeds: a Boon For Farmers. Inter. J. Sci., 6 (1): 375-380.

Sejian V, Maurya VP, Prince LLL, Kumar D, and SMK Naqvi. 2016. Effect of Body Condition Score on the Allometric Measurements and Reproductive Performance of Garole X Malpura Ewes under Hot Semi-Arid Environment. J. Dairy, Veter. Anim. Res. 3 (1): 00061-00064

Steel RGD, and JH Torrie. 1981. Principles and Procedures of Statistics. A biometric Approach. 2nd Edition, Mc Graw Hill International Book Co., Singapore.

Taye M, G Abebe, S Lemma, S Gizaw, A Mekoya, and $M$ Tibbo. 2011. Reproductive performances and Survival of washera sheep under traditional management systems at Yilmanadensa and Quarit Districts of the Amhara National Regional State, Ethiopia. J. of Anim and Veter. Adv. 10 (9): 1158-1165.

Tunji, AOI, GN Akpa, BI Nwagu, IA Adeyinka, CU Osuhor, TT Lawal, and OA Ojo. 2010. Relationship Between Gestation Length and Birth Weight in Nigerian Sheep and Their Crosses. J. Anim. Prod., 12(3): 135-138.

Thomas RAC, RE Hickson, ST Morris, PJ Back, AL Ridler, KJ Stafford, and PR Kenyon. 2015. Effects of body condition score and nutrition in lactation on twin-bearing ewe and lamb performance to weaning. New Zealand J. Agric. Res. 58 (2): 156169

Wang Y, L Yuanxiao, Z Nana, W Zhanbin, and B Junyan. 2011. Polymorphism of exon 2 of BMP 15 gene and its relationship with litter size of two Chinese Goats. Asian-Aust. J. Anim. Sci. 24 (7): 905-911. 